\title{
ZARZĄDZANIE RELACJAMI Z DOSTAWCAMI A POZYCJA KONKURENCYJNA PRZEDSIĘBIORSTW PRZEMYSŁU MEBLARSKIEGO
}

\author{
Rafał Tyszkiewicz \\ Społeczna Akademia Nauk w Łodzi \\ Wydział Zarządzania
}

\begin{abstract}
Streszczenie: W opracowaniu przedstawiono najważniejsze kwestie dotyczące relacji $\mathrm{z}$ dostawcami w kontekście pozycji konkurencyjnej przedsiębiorstwa. Celem publikacji jest określenie, w oparciu o uzyskane wyniki badań, statystycznej zależności między strategią ogólną przedsiębiorstwa, strategią doboru dostawców, mierzeniem jakości dostaw a pozycją konkurencyjną przedsiębiorstw przemysłu meblarskiego. W artykule skoncentrowano się na trzech obszarach: cechach pozycji konkurencyjnej, znaczeniu relacji z dostawcami i wynikach badań. Wyniki badań są częścią badanego przez autora problemu naukowego dotyczącego zarządzania relacjami z dostawcami jako czynnik przewagi konkurencyjnej przedsiębiorstw przemysłu meblarskiego z województwa dolnośląskiego. Opracowanie podsumowano podstawowymi wnioskami z przeprowadzonych badań.
\end{abstract}

Słowa kluczowe: pozycja konkurencyjna, relacje z dostawcami, strategia

DOI: $10.17512 /$ znpcz.2018.1.06

\section{Wprowadzenie}

Idea relacji z dostawcami daje odbiorcy nowe możliwości kształtowania konkurencyjności. Dlatego w tworzeniu systemu konkurencyjnego przedsiębiorstwa istotne znaczenie ma proces kształtowania partnerskich relacji z dostawcami. W procesie tym relacje te odgrywają ważną rolę. Dostawcy są niezbędnymi dla przedsiębiorstwa podmiotami, a ich wpływ na kształtowanie konkurencyjności odbiorcy wyraża się przede wszystkim w kreowaniu jakości i ceny produktu finalnego. $Z$ drugiej strony - ten sam odbiorca jest klientem dla dostawców, zatem wpływa na ich sukces i przetrwanie. Jeżeli spojrzymy na dostawców przez pryzmat rynku, na którym funkcjonują, wówczas będziemy mogli zauważyć, że cele ich są niemalże tożsame z celami nabywcy, z którym współpracują (z jednym wyjątkiem - ich usługi i produkty są dla odbiorcy elementem kosztów, zatem będzie on starał się minimalizować ich cenę). Dostawcy, w zamian za usługi realizowane na rzecz odbiorcy, względnie w zamian za dostarczane towary, oczekują realizacji przychodów gwarantujących im zysk oraz pewność i stabilność powiązań.

Relacje z dostawcami, ze względu na obecną rzeczywistość funkcjonowania przedsiębiorstw, mogą stanowić swego rodzaju antidotum na niepewność i burzliwość zglobalizowanego otoczenia zewnętrznego. W tym kontekście istnieje ewentualność stosowania ich jako podstawowego czynnika pozycji konkurencyjnej. Długoterminowa, ścisła współpraca $\mathrm{z}$ dostawcami może w istotny sposób pomóc przed- 
siębiorstwu w poprawie pozycji konkurencyjnej na rynku. Ich rola zaczyna odgrywać coraz większe znaczenie $\mathrm{w}$ dostarczaniu wartości nabywcom i generowaniu dla nich zysku, przy czym dostawcy odgrywają istotną rolę w kształtowaniu jakości i ceny produktu finalnego. Dostawcy kształtują jednocześnie jakość wyrobów końcowych oraz są źródłem kosztów, które ponosi przedsiębiorstwo w celu zaopatrzenia $\mathrm{w}$ materiały niezbędne do produkcji.

Relacje $\mathrm{z}$ dostawcami są najlepszym sposobem utrzymania się przedsiębiorstwa na rynku, stąd nie bez znaczenia jest wybór przemysłu meblarskiego do badań relacji $z$ dostawcami. Wybór przemysłu meblarskiego podyktowany został przede wszystkim jego wielkością, różnorodnością podmiotową i produktową, a także znaczeniem dla gospodarki, jak i dużym spektrum dostawców. Aby utrzymać swoją konkurencyjność, polski przemysł meblarski podejmuje działania zarówno w sferze inwestowania w nowoczesne technologie, systemy zarządzania, jak również działania lobbingowe na rzecz stabilizacji rynku drewna i materiałów drewnopodobnych. Pozycja konkurencyjna opiera się głównie na wysokiej jakości wytwarzanych mebli, budowaniu trwałych relacji z klientami/dostawcami i optymistycznym podejściu do wyzwań, jakie stawia rynek w myśl zasady: „Nie ma rzeczy niemożliwych". To w rynku drzewnym dostrzeżono i zrozumiano całe spektrum procesów adaptacyjnych, jakie zachodzą w polskich przedsiębiorstwach meblarskich.

Celem artykułu jest przedstawienie, w oparciu o uzyskane wyniki badań, statystycznej zależności między strategią ogólną przedsiębiorstwa, strategią doboru dostawców, mierzeniem jakości dostaw a pozycją konkurencyjną przedsiębiorstw przemysłu meblarskiego.

Artykuł ma charakter teoretyczno-empiryczny. Dla realizacji sformułowanego w nim celu i zweryfikowania postawionych hipotez wykorzystano metodę badań statystycznych. Publikacja składa się z czterech części. W pierwszej zaprezentowano znaczenie relacji $\mathrm{z}$ dostawcami. W kolejnej zostały zawarte podstawowe zagadnienia dotyczące pozycji konkurencyjnej i strategii rynkowej. Trzecia część prezentuje metodologię badań z uwzględnieniem próby badawczej i wyniki przeprowadzonych badań ankietowych dotyczących strategii ogólnej przedsiębiorstwa, strategii doboru dostawców i mierzenia jakości. W części czwartej przedstawiono założenia badawcze i wyniki dotyczące zależności pomiędzy strategią ogólną, strategią doboru dostawców, mierzeniem jakości dostaw a pozycją konkurencyjną.

\section{Znaczenie relacji z dostawcami}

Zrozumienie istoty relacji $\mathrm{z}$ dostawcami wymaga przedstawienia podstaw teoretycznych, ponieważ pojęcie „relacja” definiuje się w sposób bardzo zróżnicowany. Dokonując przeglądu literatury, zauważa się, że pojęcie to posiada wiele znaczeń. Jak zauważa A. Kolemba, w literaturze nie istnieje jednoznacznie przyjęta definicja relacji; podkreśla, że relacje to szczególny zasób niematerialny w przedsiębiorstwie obejmujący zachowania, kulturę i współdziałanie, ale w różny sposób kultywowane i objawiane przez przedsiębiorstwa, co może prowadzić do zbudowania pozycji konkurencyjnej (Kolemba 2009, s. 64). Według A. Kolemby więź łącząca przed- 
siębiorstwo-dostawcę z przedsiębiorstwem-odbiorcą winna być raczej postrzegana jako wyznacznik całokształtu wszystkich dotychczasowych interakcji.

Relacje odbiorcy z dostawcami mogą stanowić zasób strategiczny dla obu stron, czyli przyczyniać się do powstawania pozycji konkurencyjnej. Jednak nie każda relacja posiada znamiona zasobu strategicznego. Aby tak było, musi ona być pod jakimś względem wyjątkowa (unikalna) i trudna do imitacji. W przeciwnym przypadku nie będzie się przyczyniać do odróżniania przedsiębiorstwa od konkurencji. Relacje te mogą dotyczyć dwóch obszarów: po pierwsze - mogą mieć na celu zwiększenie dostępu przedsiębiorstwa do środków finansowych, po drugie - mogą dotyczyć inwestycji przedsiębiorstwa.

Jednak wielu autorów podkreśla, że w rzeczywistości biznesowej nie wszystkie trwałe relacje są oparte na pozytywnych odczuciach i dobrej woli partnerów. Znaczna ich część opiera się na zależności od zasobów dostarczanych przez kooperanta w sytuacji ograniczonej dostępności do alternatyw i wysokich kosztach zmiany kooperanta (Zieliński 2014, s. 65).

Przedsiębiorstwo może ochronić się przed utratą zbudowanej przewagi konkurencyjnej przez reinwestycje osiągniętych korzyści w odnowę potencjału konkurencyjnego. W wyniku tego procesu następuje minimalizacja utraty przewagi. Nie da się jednak uniknąć całkowitego zagrożenia ze względu na niewystarczalność środków przeznaczonych przez przedsiębiorstwo na odnowę źródeł przewagi oraz zwiększające się możliwości rywali w zakresie działań inwestycyjnych (Adamik 2000, s. 204-205).

Reasumując: relacje z dostawcami stwarzają możliwości zyskania konkurencyjności organizacji. W procesie kształtowania konkurencyjności przedsiębiorstwa istotne jest uwzględnienie kształtowania konkurencyjności zarówno w bieżącej sytuacji, jak też w perspektywie strategicznej. Ważne jest także właściwe wdrożenie zarządzania relacjami z dostawcami w odniesieniu do całej organizacji, jak i wielu jej wymiarów. Wprowadzenie zarządzania relacjami z dostawcami w sposób fragmentaryczny bądź w wybranych obszarach nie przyniesie oczekiwanych rezultatów, a co za tym idzie - nie wzmocni pozycji konkurencyjnej, a może nawet nastąpić pogorszenie się sytuacji danego podmiotu.

Budowa bliskich relacji z dostawcą, spełnianie jego potrzeb powinny być trwale wbudowane w misję i strategię każdego podmiotu. Element ten jest również podkreślany w książce T. Petersa i R. Watermana opisującej sukcesy niektórych przedsiębiorstw i analizującej ich przyczyny. „Znakomite przedsiębiorstwa są naprawdę blisko swych dostawców. Inne przedsiębiorstwa o tym mówią, a te znakomite - po prostu to robią" (Peters, Waterman 1982, s. 45).

\section{Pozycja konkurencyjna a strategia rynkowa}

Współczesne przedsiębiorstwa, chcąc zaistnieć na konkurencyjnym rynku, zmuszone są do formułowania strategii (Rokita, Jędralska 2000, s. 9), która umożliwi im pozytywne wyróżnienie się spośród konkurencji. Zauważyć należy, iż skuteczność każdej strategii zależy od właściwej realizacji dwóch powiązanych ze sobą procesów: formułowania strategii i jej implementacji. W pierwszym procesie ko- 
nieczne jest nadanie strategii odpowiednich cech, takich jak: przejrzystość, wewnętrzna spójność, odpowiedni horyzont czasowy, akceptowalny poziom ryzyka, kompatybilność z posiadanymi zasobami czy operacyjność itp. Zaś w drugim istotne jest podjęcie właściwej sekwencji działań (zmian) zmierzających do skutecznej realizacji strategii.

Wydaje się, że przedsiębiorstwa funkcjonujące $\mathrm{w}$ dzisiejszych realiach gospodarczych, chcące osiągać pozycję konkurencyjną $\mathrm{w}$ stosunku do innych przedsiębiorstw, powinny posiadać umiejętność szybkiego reagowania na zmiany sytuacji w odniesieniu do rynków, na których prowadzą swoją działalność. Takie zjawiska, jak: rosnące wymagania dostawców, dynamiczna globalizacja rynków, zaostrzająca się konkurencja, powodują, że przedsiębiorstwa posiadające wizję własnego rozwoju i współpracy z dostawcami próbują odnaleźć nowe idee, które stanowiłyby motor ich działalności i pozwoliły z sukcesem konkurować w obliczu permanentnych zmian. Odpowiedzią na te oczekiwania jest opracowanie i wdrażanie skutecznych strategii relacji odbiorcy z dostawcami, które pozwolą na dostosowanie się odbiorcy do zmiennych warunków otoczenia oraz ukształtowanie otoczenia zgodnie z jego celami w długim okresie. Przyjmuje się, że tworzenie i dostarczanie wartości w zarządzaniu relacjami stanowi klucz do osiągania efektów rynkowych zakładanych przez przedsiębiorstwo (Rudawska 2010, s. 395-396).

Budowanie długookresowych relacji z klientami ma sens jedynie wtedy, gdy wspiera realizację celów przedsiębiorstwa. Biorąc pod uwagę współczesne warunki funkcjonowania przedsiębiorstwa, nietrudno wykazać, że nawiązywanie trwałych relacji biznesowych ma niebagatelne znaczenie dla realizacji podstawowych celów ekonomicznych przedsiębiorstwa (Caputa 2015, s. 107).

Zdaniem B. Kulisy pozycja konkurencyjna to osiągnięty przez przedsiębiorstwo wynik konkurowania, miejsce przedsiębiorstwa na rynku, wyznaczone na podstawie zrealizowanej przez przedsiębiorstwo strategii konkurowania (Kulisa 2007, s. 42-43). B. Bojewska uważa, że strategie konkurowania zapewniają oczekiwaną pozycję na rynku i wiążące się z tym korzyści (Bojewska 2002, s. 111). Z kolei M.J. Stankiewicz definiuje pozycję konkurencyjną jako możliwości konkurencyjne przedsiębiorstwa widziane ex ante lub jako źródło, przejaw i miarę konkurencyjności jednocześnie (Stankiewicz 2005, s. 68). Uważa on, że w wypadku konkurencyjności przedsiębiorstw można badać konkurencyjność czynnikową i wynikową. Jego zdaniem konkurencyjność czynnikowa (czynniki jakościowe) określa długofalową zdolność firmy do szybkiego reagowania na zmiany warunków otoczenia, umiejętność wykorzystania w nim sprzyjających konfiguracji, zasobów własnych i dostępnych zasobów zewnętrznych oraz racjonalność procesów decyzyjnych. Uwzględnia ocenę takich miękkich czynników, jak: satysfakcja dostawców, lojalność, znajomość firmy i jej wyrobów na rynku, częstotliwość zakupu danego produktu, ocenę jakościowych cech produktu na tle konkurencji itp. Z kolei konkurencyjność wynikowa (czynniki ilościowe) określa efekty osiągnięte przez przedsiębiorstwo $\mathrm{w}$ procesie konkurowania, uwzględniające przede wszystkim wyniki finansowe (np. poziom rentowności i inne wyniki na tle osiągniętych przez inne przedsiębiorstwa $\mathrm{z}$ danego segmentu rynkowego), a także marketingowe (np. udział w rynku, wzrost udziału w rynku). Budowanie konkurencyjności jest dla 
współczesnych przedsiębiorstw niezbędnym warunkiem przetrwania i sprostania rynkowej rywalizacji (Kłeczek, Kowal, Woźniczka 1997, s. 56).

Często konkurencyjność wynikowa ex ante utożsamiana jest w literaturze z osiąganą przez przedsiębiorstwo pozycją konkurencyjną (Stankiewicz 2005, s. 87-88), a konkrecyjność czynnikowa z przewagą konkurencyjną przedsiębiorstwa (Gorynia 2000, s. 114). Dlatego konkurencyjność ex ante, ,[...] jest to przyszła (perspektywa) pozycja konkurencyjna. Jest ona określona przez relatywną (czyli odniesioną do umiejętności rywali) zdolność przedsiębiorstwa do konkurowania w przyszłości, czyli przez jego potencjał konkurencyjny" (Leśkiewicz 1994, s. 4). Z kolei konkurencyjność ex post to „obecna pozycja konkurencyjna” (Leśkiewicz 1994, s. 87-88). Określenie pozycji konkurencyjnej jest związane z (Leśkiewicz 1994, s. 87-88):

- ustaleniem konkurentów (uwzględnienie zarówno konkurentów bezpośrednich, jak i innych konkurentów, którzy tworzą sektor);

- wskazaniem obszarów konkurowania, które są podstawą do wyceny pozycji konkurencyjnej;

- operacjonalizacją obszarów konkurowania do poziomu empirycznie weryfikowalnego, który determinuje proces diagnozy;

- dokonaniem wyceny konkurencyjności przedsiębiorstwa we wszystkich obszarach działalności;

- określeniem syntetycznej oceny przedsiębiorstwa w stosunku do rywali lub największego konkurenta.

Można zatem przyjąć, że pozycja konkurencyjna jest osiągniętym wynikiem konkurowania $\mathrm{w}$ danym sektorze, $\mathrm{w}$ porównaniu $\mathrm{z}$ wynikami uzyskanymi przez rywali. Stanowi ona zarówno efekt podejmowanych dotychczas działań konkurencyjnych, jak i podstawę do kolejnych, a kluczowym zagadnieniem staje się jej ocena (Niezgoda 2005, s. 15-23). Strategie konkurowania pozwalają dostosować przedsiębiorstwo do zmieniających się warunków otoczenia oraz kształtować relacje z dostawcami zgodnie $\mathrm{z}$ celami przedsiębiorstwa. Z punktu widzenia problematyki kształtowania relacji z dostawcami istotną rolę odgrywają interakcje organizacji z otoczeniem w toku realizacji różnorodnych funkcji (Tyszkiewicz 2016). Dlatego, jak podkreśla D. Jelonek, „realizując międzyorganizacyjne procesy innowacji, podstawową kwestią jest monitorowanie otoczenia w celu odpowiedniego doboru partnerów" (Jelonek 2002).

\section{Metodologia badań}

\section{Cel oraz metoda prowadzenia badań}

Głównym celem badań było zbadanie zależności między:

1) strategią ogólną a pozycją przedsiębiorstwa na rynku,

2) strategią doboru dostawców a pozycją przedsiębiorstwa na rynku,

3) mierzeniem jakości dostaw a pozycją przedsiębiorstwa na rynku.

Badanie przeprowadzono metodą sondażu diagnostycznego na próbie 110 przedsiębiorstw przemysłu meblarskiego z województwa dolnośląskiego. Do realizacji 
wybranej metody zastosowano anonimową ankietę jako technikę badawczą. Natomiast narzędziem badawczym był kwestionariusz ankiety zawierający zbiór pytań stawianych pisemnie, celem uzyskania odpowiedzi mających służyć do rozwiązania szerszego problemu naukowego dotyczącego zarządzania relacjami z dostawcami. Prezentowane wyniki badań statystycznych nie są jego częścią badawczą.

Kwestionariusz ankiety kierowany był do kadry kierowniczej, szczególnie do pracowników odpowiedzialnych za kontakty z dostawcami. Badania przeprowadzono w 2016 roku i objęto nimi przedsiębiorstwa należące do branży meblarskiej. Wybór przemysłu meblarskiego podyktowany został przede wszystkim jego wielkością, różnorodnością podmiotową i produktową, a także znaczeniem dla gospodarki, jak i dużym spektrum dostawców. Przewaga konkurencyjna opiera się tu głównie na wysokiej jakości wytwarzanych mebli, budowaniu trwałych relacji z klientami/dostawcami i optymistycznym podejściu do wyzwań, jakie stawia rynek w myśl zasady: „Nie ma rzeczy niemożliwych”.

Zawarte $\mathrm{w}$ kwestionariuszu informacje dotyczące przedsiębiorstw meblarskich to głównie cechy jakościowe. W celu stwierdzenia, czy pomiędzy poszczególnymi zmiennymi (strategia ogólna, strategia doboru dostawców, mierzenie jakości dostaw, pozycja konkurencyjna) istnieje czy też nie istnieje zależność, zbadano korelację cech jakościowych (niemierzalnych). W tym celu przyjęto następujące założenia badawcze:

1. Zależność między zmiennymi X i Y jest statystycznie istotna.

2. Zmienna $X$ jest to zmienna niezależna (strategia ogólna, strategia doboru dostawców, mierzenie jakości dostaw), zaś zmienna Y jest to zmienna zależna i w moich badaniach za zmienną zależną przyjąłem pozycję przedsiębiorstwa na rynku.

3. Dane zostały zebrane w tablicach kontyngencyjnych, które stosuje się właśnie do cech niemierzalnych.

4. Zastosowano test niezależności $\chi^{2}$ (chi-kwadrat).

5. Przed przystąpieniem do badań postawiono dwie hipotezy:

H0. Istnieje niezależność statystyczna zmiennych losowych X i Y.

H1. Istnieje zależność statystyczna zmiennych losowych X i Y.

6. Do sprawdzenia testu niezależności stosuje się zmienną określoną wzorem:

gdzie:

$$
\chi^{2}=\sum_{i} \sum_{j} \frac{\left(f_{i j}-e_{i j}\right)^{2}}{e_{i j}}
$$

$f_{i j}$-obserwowana empiryczna częstość absolutna w tablicy kontyngencyjnej

w $i$-tym wierszu i $j$-tej kolumnie;

$e_{i j}$-spodziewana częstość absolutna w tablicy kontyngencyjnej w $i$-tym wierszu i $j$-tej kolumnie;

$e_{i j}=\frac{(\text { suma obserwacji } w i-\text { tym wierszu })(\text { suma obserwacji } w j-\text { tej kolumnie })}{\text { liczebność próby }}$ 
7. Jeśli $\chi^{2}>\chi_{\alpha}^{2}$, to hipotezę zerową należy odrzucić na korzyść hipotezy alternatywnej (istnienie zależności między badanymi cechami), gdzie:

- $\alpha$ jest to ustalony poziom istotności dla potrzeb badań statystycznych. Ja przyjąłem $\alpha=0,05$ (5\%).

- Liczba stopni swobody $=(l-1)(k-1)$,

- gdzie: $l$ - liczba wierszy, $k$ - liczba kolumn.

\section{Charakterystyka próby badawczej}

Do badania wybrano 110 przedsiębiorstw przemysłu meblarskiego województwa dolnośląskiego. Wybór taki wynika przede wszystkim z rosnącego znaczenia tego województwa na „mapie meblowej”. Dla przedsiębiorstw przemysłu meblarskiego województwo to jest również atrakcyjne ze względu na dogodne położenie geograficzne i sieć dróg, co ułatwia kontakty z pozostałymi krajami Unii Europejskiej. W uzyskanej grupie odpowiedzi otrzymano wskaźnik responsywności na poziomie $24,4 \%$. W badaniach (polskich i zagranicznych) wynik ten nie odbiega od przeciętnego poziomu realizowanej próby badawczej. Rzutuje to na możliwość występowania określonych tendencji w zakresie badanego zjawiska, choć pozwala na dokonanie pewnych uogólnień i wniosków w stosunku do badanej populacji. $\mathrm{Z}$ danych uzyskanych $\mathrm{z}$ przedsiębiorstw meblarskich $\mathrm{z}$ województwa dolnośląskiego utworzono bazę, która stanowiła bogaty materiał badawczy. O wyborze przedsiębiorstw zadecydowały następujące kryteria:

- zróżnicowanie regionalne - region dolnośląski z podziałem na miasta i gminy,

- podstawowe produkty i okres prowadzenia działalności,

- wielkość zatrudnienia,

- forma organizacyjno-prawna,

- podstawowy profil działalności.

W badanej grupie najliczniej reprezentowane są przedsiębiorstwa założone w latach 2000-2009, stanowią one 46,4\% ogólnej liczby badanych przedsiębiorstw (tj. 51 na 110). Wśród respondentów znaczną część reprezentują przedsiębiorstwa powstałe w latach 1990-1999, co stanowi 37,2\% (41 przedsiębiorstw). Przed 1989 rokiem założono 17 przedsiębiorstw (15,5\%). Stosunkowo najmniejszą grupę stanowią przedsiębiorstwa założone po 2010 roku $(0,9 \%)$. Taki rozkład przedsiębiorstw ma swoje uzasadnienie w przemianach społeczno-gospodarczych zachodzących w Polsce.

Wśród przedsiębiorstw meblarskich biorących udział w badaniu $70,9 \%$ to mikroprzedsiębiorstwa, natomiast $19,1 \%$ to firmy małe. Średnie przedsiębiorstwa stanowią $8,2 \%$ próby badawczej, natomiast udział dużych przedsiębiorstw w ogólnej próbie wynosi $1,8 \%$.

W odpowiedzi na pytanie, czy badane przedsiębiorstwa mają opracowaną strategię i w jakiej formie, większość respondentów stwierdziła, że ma taką strategię opracowaną: $34,5 \%$ ankietowanych (38 spośród 110) odpowiedziało, że przedsiębiorstwo ma opracowaną strategię - spisany, oficjalny dokument, a $28,2 \%$ ankietowanych (31) stwierdziło, że przedsiębiorstwo posiada strategię, ale nieformalną, czyli 
są to spisane zasady długoterminowego programowania działalności przedsiębiorstwa. Natomiast 20,1\% ankietowanych przyznało, że w ich przedsiębiorstwach taką strategię albo opracowuje się, albo planuje się opracować w przyszłości, a 16,2\% przebadanych przedsiębiorstw meblarskich (tj. 18) nie ma opra-cowanej formalnej ogólnej strategii przy jednoczesnym samozadowoleniu z zajmo-wanej pozycji konkurencyjnej na obsługiwanym rynku.

Uwzględnianie relacji z dostawcami w ogólnej strategii w dużej mierze zależne jest od pozycji przedsiębiorstwa na obsługiwanym rynku. Badane przedsiębiorstwa najczęściej określały swoją pozycję jako silniejszą od głównych konkurentów, ale zdecydowanie nie jako lidera. Tę kategorię wybrało 37 przedsiębiorstw. Następna wybierana na obsługiwanym rynku jest pozycja lidera pod względem jakości (30 przedsiębiorstw), na trzecim zaś miejscu uplasowała się pozycja dominująca (25), tylko 8 przedsiębiorstw określiło swoją pozycję jako lidera pod względem kosztów.

Najczęściej wymieniane silniejsze pozycje od głównych konkurentów wskazują, że w badaniach wzięły udział przedsiębiorstwa o możliwościach zdobywania przewagi konkurencyjnej. Z punktu widzenia założeń badawczych może to stanowić znaczące potwierdzenie. To, że większość badanych przedsiębiorstw (70,9\%) posiada ogólną strategię uwzględniającą relacje z dostawcami, jako dokument - oficjalny lub nieoficjalny, może wiązać się z tak silną pozycją tych przedsiębiorstw.

Uwzględniając formę opracowania strategii doboru dostawców, większość badanych przedsiębiorstw stwierdziła, że ma opracowaną strategię doboru dostawców w formie dokumentu. Spośród 110 badanych 40,9\% ma taką strategię jako dokument, u 25,4\% strategia jest $\mathrm{w}$ trakcie opracowywania, $17,3 \%$ respondentów nie ma opracowanej strategii doboru dostawców, ale zamierza ją opracować, a 16,4\% nie ma. Odpowiedzi świadczą o tym, że podejmowane są czynności nad opracowaniem strategii doboru dostawców w formie oficjalnego dokumentu.

$\mathrm{W}$ prowadzonych badaniach respondenci dokonali również obiektywnej oceny kryteriów jakości dostaw. Z badań wynika, iż zdecydowana większość badanych przedsiębiorstw $(56,4 \%)$ wskazuje jako kryterium jakości dostaw poprawność zrealizowanych zamówień (na czas i właściwe miejsce, bez uszkodzeń, w odpowiedniej ilości i strukturze, z bezbłędną dokumentacją), a 25,4\% wskazuje terminowość realizacji dostaw. $\mathrm{Z}$ kolei $9,1 \%$ przedsiębiorstw określa jako kryterium jakości dostaw dostępność zamówionego towaru bezpośrednio z posiadanego zapasu magazynowego i taki sam procent nie mierzy poziomu jakości. Dzięki współpracy z dostawcami zdolnymi do realizacji zamówień dokładnie na czas można wyeliminować znaczne koszty. Dlatego dobry dostawca to taki, który dostarcza zamawiane surowce i materiały dokładnie w czasie, kiedy są oczekiwane, w uzgodnionej ilości i na właściwe miejsce.

W badaniach ankietowych ocenie poddano także aktualny system zarządzania relacjami z dostawcami w kontekście kształtowania pozycji konkurencyjnej. W tym celu poproszono respondentów o przygotowanie oceny sformułowanych twierdzeń znaczenia danego zakresu systemu zarządzania relacjami z dostawcami.

Badani respondenci wskazali, że system zarządzania relacjami $\mathrm{z}$ dostawcami umożliwia racjonalne wykorzystanie zasobów przedsiębiorstwa $(55,4 \%)$ i uzyski- 
wanie na bieżąco informacji o wysokości jego wykorzystanych zasobów w zakresie współpracy z dostawcami (51,8\%). Wysokie noty (ponad 40\%) osiągają także takie kategorie, jak: oparcie systemu zarządzania relacjami z dostawcami na racjonalnych analizach i faktycznych potrzebach zgłaszanych przez pracowników i dostawców (46,4\%), systematyczne otrzymywanie z systemu sprawozdawczości informacji o osiąganiu przez przedsiębiorstwo wyznaczonych celów z dostawcami $(44,6 \%)$ i o relacjach $\mathrm{z}$ dostawcami $\mathrm{w}$ trakcie realizowanych zadań $(43,6 \%)$ oraz umożliwianie przez system informacji racjonalnego podejmowania decyzji.

Relacje $\mathrm{z}$ dostawcami należą do trudnych problemów $\mathrm{w}$ przedsiębiorstwach i stanowią źródło ich pozycji konkurencyjnej. Z kolei pozycja konkurencyjna jest istotnym problemem $\mathrm{w}$ teoriach dotyczących konkurencji i stanowi podstawę $\mathrm{w}$ rozważaniach na temat funkcjonowania i rozwoju przedsiębiorstwa $\mathrm{w}$ ogóle. $\mathrm{Z}$ jednej strony wzajemnie korzystne relacje umożliwiają i warunkują dostarczanie wyrobów na najkorzystniejszych warunkach - są one traktowane jako podstawa formułowania strategii rozwoju przedsiębiorstwa. Z drugiej strony przedsiębiorstwa upatrują w kształtowaniu relacji z dostawcami szansę na osiągnięcie pozycji konkurencyjnej, bo przecież konkurencyjność przedsiębiorstwa na rynku uzależniona jest od dostawców surowców, komponentów i opakowań.

\section{Badania}

W pierwszej kolejności dokonano badania zależności między strategią ogólną a pozycją przedsiębiorstwa na rynku. Przyjęto, że:

- Zmienna X (niezależna) to strategia ogólna przyjęta przez przedsiębiorstwo.

- Zmienna Y (zależna) to pozycja przedsiębiorstwa na rynku.

Zawartość tabeli kontyngencyjnej prezentuje Tabela 1, w której przedstawiono warianty zmiennej X i Y.

Tabela 1. Zawartość tabeli kontyngencyjnej

\begin{tabular}{|c|c|c|c|}
\hline \multirow{2}{*}{$\begin{array}{c}\text { Warianty zmiennej } \\
\text { Y } \\
\text { (pozycja na rynku) }\end{array}$} & \multicolumn{3}{|c|}{ Warianty zmiennej X (stosowanie strategii ogólnej) } \\
\cline { 2 - 4 } & stosowana & niestosowana & ogółem \\
\hline Istotna & 120 & 30 & 150 \\
\hline Nieistotna & 30 & 20 & 50 \\
\hline Ogółem & 150 & 50 & 200 \\
\hline
\end{tabular}

Źródło: Opracowanie własne

Na poziomie istotności $\alpha=0,05$ zbada się, czy pozycja przedsiębiorstwa zależy od strategii ogólnej przyjętej przez przedsiębiorstwo. W tym celu postawiono dwie hipotezy:

$H_{0}$ : Pozycja przedsiębiorstwa nie zależy od przyjętej strategii ogólnej.

$H_{1}$ : Pozycja przedsiębiorstwa zależy od przyjętej strategii ogólnej. 
W Tabeli 2 przedstawiono liczebności zmiennych oczekiwanych i empirycznych.

Tabela 2. Liczebności zmiennych oczekiwanych i empirycznych

\begin{tabular}{|c|c|c|c|}
\hline $\begin{array}{c}\text { Zmiana pozycji } \\
\text { na rynku }\end{array}$ & $\begin{array}{c}\text { Stosowanie } \\
\text { strategii ogólnej }\end{array}$ & $\begin{array}{c}\text { Niestosowanie } \\
\text { strategii ogólnej }\end{array}$ & Ogółem \\
\hline Wzrasta & 112 & 38 & 150 \\
\hline Bez zmian & 38 & 12 & 50 \\
\hline Ogółem & 150 & 50 & 200 \\
\hline
\end{tabular}

Źródło: Opracowanie własne

Na podstawie danych zaprezentowanych w Tabeli 2 test niezależności wynosi: $\chi^{2}=9,273$. Przyjmując poziom istotności $\alpha=0,05$ przy jednym stopniu swobody $\chi_{\alpha}^{2}=3,841$, możemy sformułować następujący wniosek:

$Z$ uwagi na fakt, że $\chi^{2}=9,273>\chi_{\alpha}^{2}=3,841$, odrzucamy hipotezę zerową na rzecz alternatywnej. Możemy zatem stwierdzić, że na poziomie istotności 0,05 pozycja przedsiębiorstwa na rynku zależy od przyjętej strategii ogólnej przez przedsiębiorstwo.

W drugiej kolejności dokonano badania zależności: między strategią doboru dostawców a pozycją przedsiębiorstwa na rynku. Przyjęto, że:

- Zmienna X (niezależna) to strategia doboru dostawców przez przedsiębiorstwo.

- Zmienna Y (zależna) to pozycja przedsiębiorstwa na rynku.

Zawartość tabeli kontyngencyjnej prezentuje Tabela 3, w której przedstawiono warianty zmiennej X i Y.

Tabela 3. Zawartość tabeli kontyngencyjnej

\begin{tabular}{|c|c|c|c|}
\hline \multirow{2}{*}{$\begin{array}{c}\text { Warianty zmiennej } \\
\text { Y } \\
\text { (pozycja na rynku) }\end{array}$} & \multicolumn{3}{|c|}{ Warianty zmiennej X (stosowanie strategii doboru dostawców) } \\
\hline & stosowana & niestosowana & ogółem \\
\hline Istotna & 90 & 30 & 120 \\
\hline Nieistotna & 60 & 20 & 80 \\
\hline Ogółem & 120 & 80 & 200 \\
\hline
\end{tabular}

Źródło: Opracowanie własne

Na poziomie istotności $\alpha=0,05$ zbadamy, czy pozycja przedsiębiorstwa zależy od strategii doboru dostawców.

$H_{0}$ : Pozycja przedsiębiorstwa nie zależy od przyjętej strategii doboru dostawców. $H_{1}$ : Pozycja przedsiębiorstwa zależy od przyjętej strategii doboru dostawców.

Tabela 4. Liczebności zmiennych oczekiwanych i empirycznych

\begin{tabular}{|c|c|c|c|}
\hline $\begin{array}{c}\text { Zmiana pozycji } \\
\text { na rynku }\end{array}$ & $\begin{array}{c}\text { Stosowanie strategii } \\
\text { doboru dostawców }\end{array}$ & $\begin{array}{c}\text { Niestosowanie strategii } \\
\text { doboru dostawców }\end{array}$ & Ogółem \\
\hline Wzrasta & 72 & 48 & 120 \\
\hline Bez zmian & 48 & 32 & 80 \\
\hline Ogółem & 120 & 80 & 200 \\
\hline
\end{tabular}

Źródło: Opracowanie własne 
Na podstawie danych zaprezentowanych w Tabeli 4 test niezależności wynosi: $\chi^{2}=18,75$. Przyjmując poziom istotności $\alpha=0,05$ przy jednym stopniu swobody $\chi_{\alpha}^{2}=3,841$, możemy sformułować następujący wniosek:

$\mathrm{Z}$ uwagi na fakt, że $\chi^{2}=18,75>\chi_{\alpha}^{2}=3,841$, odrzucamy hipotezę zerową na rzecz alternatywnej. Możemy zatem stwierdzić, że na poziomie istotności 0,05 pozycja przedsiębiorstwa na rynku zależy od przyjętej strategii doboru dostawców.

W trzeciej kolejności dokonano badania zależności: między strategią doboru dostawców a pozycją przedsiębiorstwa na rynku. Przyjęto, że:

- Zmienna X (niezależna) to mierzenie jakości dostaw przez przedsiębiorstwo.

- Zmienna Y (zależna) to pozycja przedsiębiorstwa na rynku.

Tabela 5. Zawartość tabeli kontyngencyjnej

\begin{tabular}{|c|c|c|c|}
\hline \multirow{2}{*}{$\begin{array}{c}\text { Warianty zmiennej } \\
\text { Y } \\
\text { (pozycja na rynku) }\end{array}$} & \multicolumn{3}{|c|}{ Warianty zmiennej X (stosowanie mierzenia jakości dostaw) } \\
\cline { 2 - 4 } & stosowana & niestosowana & ogółem \\
\hline Istotna & 120 & 40 & 160 \\
\hline Nieistotna & 30 & 10 & 40 \\
\hline Ogółem & 150 & 50 & 200 \\
\hline
\end{tabular}

Źródło: Opracowanie własne

Na poziomie istotności $\alpha=0,05$ zbadamy, czy pozycja przedsiębiorstwa zależy od mierzenia jakości dostaw.

$H_{0}$ : Pozycja przedsiębiorstwa nie zależy od mierzenia jakości dostaw.

$H_{1}$ : Pozycja przedsiębiorstwa zależy od mierzenia jakości dostaw.

Tabela 6. Liczebności zmiennych oczekiwanych i empirycznych

\begin{tabular}{|c|c|c|c|}
\hline $\begin{array}{c}\text { Zmiana pozycji } \\
\text { na rynku }\end{array}$ & $\begin{array}{c}\text { Mierzenie jakości } \\
\text { dostaw }\end{array}$ & $\begin{array}{c}\text { Niedokonywanie } \\
\text { pomiaru jakości dostaw }\end{array}$ & Ogółem \\
\hline Wzrasta & 128 & 32 & 160 \\
\hline Bez zmian & 22 & 18 & 40 \\
\hline Ogółem & 150 & 50 & 200 \\
\hline
\end{tabular}

Źródło: Opracowanie własne

Na podstawie danych zaprezentowanych w Tabeli 6 test niezależności wynosi: $\chi^{2}=8,965$. Przyjmując poziom istotności $\alpha=0,05$ przy jednym stopniu swobody $\chi_{\alpha}^{2}=3,841$, możemy sformułować następujący wniosek:

$\mathrm{Z}$ uwagi na fakt, że $\chi^{2}=8,965>\chi_{\alpha}^{2}=3,841$, odrzucamy hipotezę zerową na rzecz alternatywnej. Możemy zatem stwierdzić, że na poziomie istotności 0,05 pozycja przedsiębiorstwa na rynku zależy od mierzenia jakości dostaw. 


\section{Podsumowanie}

Analiza materiału badawczego skłania do następujących wniosków:

- Wyniki badań są dowodem na to, iż przedsiębiorstwa przemysłu meblarskiego zdają sobie sprawę, jak ważnym elementem w zarządzaniu relacjami z dostawcami jest ich uwzględnianie w opracowanej strategii. Uzyskane odpowiedzi świadczą o tym, że przedsiębiorstwa zaczynają dbać o dostawców i starać się o nawiązywanie z nimi partnerskich relacji, z uwagi na konkurencyjność rynku. Na uwagę zasługuje wskazanie, iż zdecydowana większość przedsiębiorstw jest świadoma relacji z dostawcami, czego wyraz daje w strategii ogólnej, ponieważ ich uwzględnianie pozwala efektywnie wykorzystać posiadane zasoby, skupić się na sprawach najważniejszych dla rozwoju przedsiębiorstwa, lepiej zrozumieć potrzeby dostawców i usprawnić relacje z nimi, udoskonalić podejmowane decyzje oraz zwiększa prawdopodobieństwo wygrania walki konkurencyjnej.

- Większość przedsiębiorstw przemysłu meblarskiego z województwa dolnośląskiego ma sformułowane kryteria stosowania doboru dostawców.

- Badania statystyczne umożliwiły weryfikację pierwszej i drugiej hipotezy badawczej postawionej w rozdziale.

Poziom istotności 5\% to najbardziej popularny i chyba najczęściej przyjmowany w prezentowanych przez różnych autorów artykułach. Na poziomie ufności 95\% dokonujemy odrzucenia hipotezy zerowej na rzecz alternatywnej, czyli w naszym przypadku stwierdzamy, że na poziomie ufności $95 \%$ pozycja przedsiębiorstwa na rynku zależy od przyjętej strategii ogólnej, od strategii doboru dostawców oraz od mierzenia jakości dostaw przez przedsiębiorstwo.

\section{Literatura}

1. Adamik A. (2000), Przymus budowy przewagi konkurencyjnej jako wymóg nowoczesnego zarządzania przedsiębiorstwem, [w:] Jeżak J. (red.), Rozwój teorii i praktyki zarzadzania strategicznego, Polsko-Amerykańskie Centrum Zarządzania, Łódź, s. 204-205.

2. Bieńkowski W. (1995), Reaganomika i jej wpływ na konkurencyjność gospodarki amerykańskiej, Wydawnictwo Naukowe PWN, Warszawa.

3. Bojewska B. (2002), Przedsiębiorczość w zarzadzaniu i rozwoju matych i średnich przedsiębiorstw, [w:] Strużycki M. (red.), Zarządzanie małym i średnim przedsiębiorstwem. Uwarunkowania europejskie, Difin, Warszawa, s. 107-141.

4. Caputa W. (2015), Kapital klienta $w$ budowaniu wartości przedsiębiorstwa, CeDeWu, Warszawa.

5. Gorynia M. (2000), Zachowanie przedsiębiorstw w okresie transformacji, Akademia Ekonomiczna w Poznaniu, Poznań.

6. Jelonek D. (2002), Systemy komputerowego wspomagania monitorowania otoczenia przedsiębiorstwa, Wydawnictwo Wydziału Zarządzania Politechniki Częstochowskiej, Częstochowa.

7. Jelonek D., Turek T. (2015), Kreowanie przedsiębiorczości. Perspektywa procesów i technologii informacyjnych, Wydawnictwo Wydziału Zarządzania Politechniki Częstochowskiej, Częstochowa.

8. Kłeczek R., Kowal W., Woźniczka J. (1997), Strategiczne planowanie marketingowe, PWE, Warszawa. 
9. Kolemba A. (2009), Relacje przedsiębiorstwa z otoczeniem jako instrument budowania przewagi konkurencyjnej, [w:] Cisek M. (red.), Kapitat relacyjny w nowoczesnej gospodarce, Studio Emka, Warszawa, s. 64-65.

10. Kulisa B. (2007), Teoretyczne aspekty konkurencyjności przedsiębiorstw, [w:] Nehring A. (red.), Rozwój i konkurencyjność małych i średnich przedsiębiorstw w Polsce, Wydawnictwo Uniwersytetu Ekonomicznego w Krakowie, Kraków, s. 22-49.

11. Leśkiewicz Z. (1994), Racjonalność w ekonomii, Wydawnictwo Naukowe Uniwersytetu Szczecińskiego, Szczecin.

12. Niezgoda D. (2005), Zysk ekonomiczny jako wyznacznik pozycji konkurencyjnej przedsiębiorstwa, [w:] Niezgoda D. (red.), Sposoby budowy i oceny pozycji konkurencyjnej przedsiębiorstwa, Katedra Ekonomiki i Organizacji Agrobiznesu Akademii Rolniczej, Lublin, s. $15-23$.

13. Peters T.I., Waterman R.H. (1982), In Serach of Excellence, Harper \& Row, New York London.

14. Rokita J., Jędralska K. (2000), Zarządzanie strategiczne, Górnośląska Wyższa Szkoła Handlowa, Katowice.

15. Rudawska E. (2010), Koncepcja wartości w relacjach pracownik - organizacja, „Studia i Prace Wydziału Nauk Ekonomicznych i Zarządzania”, nr 39, t. 2, s. 393-405.

16. Stankiewicz J.M. (2005), Konkurencyjność przedsiębiorstwa. Budowanie konkurencyjności przedsiębiorstwa w warunkach globalizacji, TNOiK „Dom Organizatora”, Torun.

17. Tyszkiewicz R. (2016), Zarzadzanie relacjami z interesariuszami organizacji, Agencja Wydawnicza Placet, Warszawa.

18. Urbanowska-Sojkin E., Banaszyk P., Witczak H. (2004), Zarzadzanie strategiczne przedsiębiorstw, PWE, Warszawa.

19. Zieliński M. (2014), Siła w relacjach biznesowych, „Studia Ekonomiczne”, nr 182: Zarzadzanie relacjami w biznesie, wspótczesne wyzwania, s. 65-75.

\title{
RELATIONSHIPS WITH SUPPLIERS AND COMPETITIVE ADVANTAGE OF FURNITURE INDUSTRY
}

\begin{abstract}
The article presents the most important issues regarding the relationships with suppliers in the context of the company's competitive advantage. The aim of the study is to determine the statistical dependence between the company's overall strategy, suppliers selection strategy, measuring the quality of deliveries and the competitive position of companies from the furniture industry. The article focuses on three areas: features of a competitive position, the importance of relationships with suppliers, and the research results. The results of the research are part of the scientific problem investigated by the author concerning managing relations with suppliers as a factor of competitive advantage of companies from the furniture industry from Lower Silesia. The paper summarizes the main conclusions of the research.
\end{abstract}

Keywords: competitive advantage, relationships with suppliers, strategy 